\title{
VENEREAL DISEASES ATTENDANTS
}

A LARGE number of men have received an excellent training as attendants in naval and military wards for the treatment of venereal diseases. Many of these men are now, unfortunately, out of work, and we have the permission of the following to publish their names as desirous of employment in venereal diseases treatment centres. We hope in this way to be of service both to some of these men and to treatment centres which are searching for suitable attendants, but our publication of these names implies no guarantee of their quality. In the event of any of the men named below being engaged by treatment centres we ask that we may be informed of the fact, in order that the names may be removed from the list.

Baldwin, T. D., 94, Mannington Road, Leytonstone, E. II.

Served in Military Hospital, Rochester Row, from I907 to I9ro, and in Pathological Laboratory, R.A.M. College, from I9I6 to I92I. Qualified R.A.M.C. dispenser and clerk. Prefers south-eastern counties. Requires a minimum of $£ 4$ per week.

BAncroft, Frank, 66, Hazelbourne Road, Balham, S.W. I2.

Served in V.D. Wards, British Army Hospital, Danzig, January to November 3oth, I920, and from January, I92I, to November, I923, in 25th General Hospital (V.D.), Rhine Army. Also 6 months in V.D. Department, St. Thomas's Hospital. Willing to serve in any part of Britain. Wages $£ 4$ per week.

Bourns, L., 6, Hillmore Grove, Lower Sydenham, S.E.

Trained R.A.M.C. V.D. Orderly, for which holds first-class certificate. Six years' experience. Free in February, 1929. Willing to reside anywhere. Wages as paid to other workers performing similar duties.

Burns, J. S., Corporal R.A.M.C., District Laboratory, Royal Herbert Hospital, Woolwich.

Age 29. Laboratory assistant ; dispenser ; male nurse. I2 years' experience in V.D. work. Carries 7 excellent testimonials as laboratory attendant and N.C.O. Available for permanent employment. Wages $£ 3$ Ios. to $£ 4$ a week. 


\section{BRITISH JOURNAL OF VENEREAL DISEASES}

CAdDick, B., c/o 4, Pattison Road, Child's Hill, Hampstead, N.W. 2. Sick berth attendant, R.N., 7 years. Claims experience in all branches of V.D., including staining and taking of blood specimens. Has Surgeon-Commander's testimonial as to reliability and efficiency. London neighbourhood preferred. Usual wages.

Coxon, W. J., I62, Cartwell Road, Woodseats, Sheffield.

Late R.A.M.C. Qualified in Army as Dispenser and V.D. Attendant, both first-class. Well acquainted with microscopical tests and all work connected with treatment of V.D.

Croft, A. T., 4, St. Aubyn's Terrace, Chipstead Valley Road, Coulsdon, Surrey.

Ten years' experience during the War.

Cullingworth, W. A., 33, Greville Road, Walthamstow, E. I7.

Ex-Private R.A.M.C. Has considerable experience as attendant in military V.D. hospitals. First-class testimonials on reliability, nursing, and particularly on clerical ability.

Deva, Anthony, I6, Arthur Street (Ist floor), New Oxford Street, London, W.C. 2.

Ex-Lance Sergeant, R.A.M.C. Dispenser, Nursing orderly and Clerk. Was employed in Military V.D. Hospital, Rhine Army. Willing to serve anywhere. Commencing wage $£ 3$.

Evans, F. C., I7, Clyde Road, Silvertown, E. I6.

Seven year's service R.A.M.C. Exemplary character. Qualified laboratory attendant. Four years' experience as V.D. attendant and laboratory assistant V.D. sections of military hospitals. Prefers London, but would go anywhere. Wages $£ 3$ per week minimum.

Exelby, J. F., 3, Elsworth Square, Pudsey, Leeds.

Served in No. 39 General Hospital, France, during the War and subsequently in a V.D. Centre in Canada under one of the officers for whom he had worked in No. 39. Became unemployed on account of the Canadian Centre being discontinued. Has excellent references from officers under whom he served. Willing to serve anywhere at usual wages.

FiELd, W. H., I6, Main Street, Gorbals, Glasgow.

Ex-Lance Sergeant, R.A.M.C. Dispenser and nurse ; 2 I years in Army ; was in charge of Lock Wards, Royal Victoria Hospital, Netley ; Piershill, Edinburgh ; Maryhill, Glasgow ; also on troopships. Served as senior male nurse for $12 \frac{1}{2}$ years, Royal Infirmary, Glasgow. Thoroughly experienced in usual routine of V.D. work. Minimum wage $£ 4$.

Forsyth, W., 4, Central Road, Crombie, Dunfermline, Fife.

Late Pte., R.A.M.C. : $3 \frac{1}{2}$ years' experience in a Military V.D. Hospital. Has excellent testimonial from R.A.M.C. specialist as to reliability, knowledge and skill in all branches of this work, including clerical and microscopical. 


\section{VENEREAL DISEASES ATTENDANTS}

Fowler, Leonard, 2, Northcote Street, New Street, Farsley, near Leeds.

Served in Colchester and Warley Military Hospitals from IgI6 to I9I7, and in 3rd British General Hospital in Mesopotamia from I9I9 to I92I. Desires employment in Norwich, Wales or Leeds at standard wages.

Higginson, Albert, I, Brigade Place, South Street, S.E. Io.

Aged 25. Married. Seven years' service in R.A.M.C. Passed as first-class nursing orderly and as V.D. orderly. Employed 5 years as V.D. attendant Aldershot, for which he has excellent testimonial.

Hoskins, D., 40, Ashford Street, Shelton, Stoke-on-Trent (ex-Petty Officer, Ist Class, R.N.).

Served in Naval Hospitals at Chatham and Eastchurch from I9I6 to r9I9, gaining full experience as a V.D. attendant, including staining of specimens. Would serve anywhere, but prefers south or south-west. Wages $£ 3$ per week with free quarters, or board and ledging and washing of overalls.

Howell, Chas. E., 323, Southampton Street, Camberwell, S.E. 5 .

Age 47. Widower. V.D. experience four years in No. $5 \mathrm{I}$ General Hospital, Ministry of Pensions Hospital, Epsom, October, I920, till June, I925. Willing to serve anywhere. Wages by arrangement.

Humphries, J., Poste Restante, Post Office, Charing Cross, S.W. I.

Served for $9 \frac{1}{2}$ years as R.A.M.C. Nurse. Qualified male nurse and laboratory attendant. Also served as male nurse in Royal NorthWest Mounted Police, Canada, and in Royal Canadian Air Force. Claims considerable experience as a V.D. attendant. Willing to serve anywhere.

Kincaid, F., 70, Bromfielde Road, Clapham, S.W. 4.

Has worked in Military V.D. Hospitals or sections of such for some years. Possesses certificates for Fducation, Nursing and Special Treatment. Prefers London or anywhere in the Home Counties. Usual wages.

Martin, L., I5, Salop Street, Oldbury, nr. Birmingham.

Twelve years' experience in Military (V.D.) Hospitals. Has had laboratory experience.

PaIn, J., 373, Ordnance Road, Enfield Lock, Middlesex.

Single. Age 27. Late Cpl. R.A.M.C. 7 years' experience in V.D. Sections of Military Hospitals. Bears excellent testimonials as to ability, skill and thorough reliability in all duties of V.D. attendant. Army character exemplary. Willing to serve anywhere. Wages usual.

Powell, A. E., Pte., R.A.M.C., Royal Herbert Hospital, Woolwich.

Has testimonials to ability in special treatment work and preparation of microscopical specimens.

Powell, E., 46, Earlsfield Road, London, S.W. I8.

Age 34. Late Corporal R.A.M.C. Has acted as N.C.O. i/c Treatment Centre of V.D. Cases at Military Hospital, Glasgow. Has testimonial as to reliability and efficiency. Willing to serve in any part of the country. Could report at any time. Would like $£ 3$ per week. 


\section{BRITISH JOURNAL OF VENEREAL DISEASES}

QuAyle, J. J., 84, Exeter Street, Bradford.

Trained R.A.M.C. V.D. attendant, and served for about 4 years in various Military V.D. Hospitals before and during the War. Wishes to work in Bradford, Leeds, Halifax or Keighley. Wages $£ 3$ Ios. a week.

Ransome, D. C., 77, High Street, Bexley, Kent (late R.A.M.C.).

Employed in V.D. sections of Military Hospitals I9Io to I9I3, and in V.D. work in Ministry of Pensions Hospitals I9I9 to I929. Good references. Married. One child. Wages $£ 4$ to $£ 5$ per week.

REed, Frederic, 4I, Bridge Road, Stockton-on-Tees.

Employed from I922 to I927 in V.D. sections of Military Hospitals. Holds good testimonials and Army certificate as first-class specialtreatment orderly. Willing to serve anywhere in Great Britain. Wages 4 guineas per week.

Sangster, B., c/o Mrs. F. Mutch (Jnr.), 4, Seaforth Road, Aberdeen.

Late Corporal R.A.M.C. Was V.D. Orderly at York for a year. Has testimonial to intelligence, smartness and energy. Willing to work anywhere. Wages $£ \mathrm{I}$ per week with all found.

SNow, Robert, 53, Fenwick Street, Woolwich Common, S.E. r8.

About 7 years' experience prior to the War in various Military Hospitals and Wards. Prefers London. Wages $£ 4$ per week.

Tatham, E. H., 8, Osborne Road, Tuebrook, Liverpool.

Experience in the treatment of Venereal Diseases, 6 years. Qualification held: Special Treatment Orderly (Army), Class r. Desirous of taking up a post as Assistant in Clinic or Assistant in Private Practice (V.). Available in May-June. Salary required, $£ 250$, or thereabouts, per annum.

Tollast, William W., 2, Lebanon Gardens, West Hill, Wandsworth, S.W. I8.

Pensioned Chief Sick-berth Petty Officer, R.N.; 22 years' service includes V.D. work. Testimonials to reliability, adaptability, and particularly to clerical ability.

Vernum, H. C., 40, Ewart Grove, Wood Green, N. 22.

Ex Sick-berth Chief Petty Officer, R.N.: 22 years' service with experience in V.D. throughout. Prefers London N. or W. Wages $£ 4$ per week.

Watkin, Frank L., 46, Foster Road, Lalue Road, Portsmouth.

Experience in V.D. for a number of years at Royal Naval Hospitals, Haslar and Malta. Has Surgeon-Captain's and Surgeon-Commander's testimonials as to reliability and efficiency. Prefers London or Portsmouth. Wages $£ 33$ s.

YATES, W. F., 24, Brookhill Road, Woolwich.

Served at Royal Herbert Hospital, Woolwich, as Special Treatment Orderly since May, I927. Carries testimonial as to training from Major E. C. Lambkin, R.A.M.C. 